\title{
Chemical composition and cytotoxic potency of essential oil from Seseli petraeum M. Bieb. (Apiaceae)
}

\author{
Alev ÖNDER ${ }^{1 *}(\mathbb{D})$, Ahsen Sevde ÇINAR ${ }^{1,2}$ (D) , Filiz BAKAR-ATEŞ ${ }^{3}$ (D) Luis NOGUERA-ARTIAGA ${ }^{4}$ \\ Ángel Antonio CARBONELL-BARRACHINA 4 (D)
}

1 Department of Pharmacognosy, Faculty of Pharmacy, Ankara University, Av. Dögol, 4, Yenimahalle, 06100, Ankara, Turkey

2 Department of Pharmaceutical Botany/Pharmacognosy, Faculty of Pharmacy, Lokman Hekim University, Av. 2179, 6, Söğütözü, 06510, Ankara, Turkey

3 Department of Biochemistry, Faculty of Pharmacy, Ankara University, Av. Dögol, 4, Yenimahalle, 06100, Ankara, Turkey

4 Department of Agro-Food Technology Research Group ‘Food Quality and Safety, Universidad Miguel Hernández de Elche, Carretera Beniel, Orihuela, Alicante, Spain

* Corresponding Author. E-mail: pharmacogalev@gmail.com (A.O.); Tel. +90-312-203 3089.

Received: 25 October 2020 / Revised: 11 March 2021/ Accepted: 26 March 2021

ABSTRACT: The present study aimed to investigate the chemical composition and in vitro cytotoxic activity of the fruit essential oil of Seseli petraeum M. Bieb. growing in the Northern side of Anatolia. The Seseli petraeum essential oil was obtained by hydrodistillation from the fruits and analyzed by GC/MS to determine its chemical composition. The major components have been determined as carotol $(17.25 \%), \gamma$-terpinene $(10.73 \%), \beta$-farnesene $(8.50 \%), p$-cymene $(7.93 \%)$, germacrene-D $(7.65 \%)$, and sabinene $(7.31 \%)$. The cytotoxic activity of the essential oil was evaluated by MTT assay in vitro on cell proliferation with MCF-7 (Human breast adenocarcinoma) and A549 (Human lung carcinoma) cells. The results showed that the essential oil has potent cytotoxicity against treated cancer cells, whereas it was more cytotoxic in MCF-7 cells $\left(\mathrm{IC}_{50}=390.38 \mu \mathrm{g} / \mathrm{mL}\right)$. The results demonstrated that $S$. petraeum essential oil has a marked cytotoxic effect against treated cancer cells. Although this effect is likely to be caused by carotol owing to a major component of the oil, further designed studies are necessary due to the possibility of activity, and maybe it occurred due to the synergistic effects of the oil components. The findings of this study may promote the use of the species for pharmaceutical purposes.

KEYWORDS: Apiaceae; anticancer; cytotoxicity; essential oil; Seseli.

\section{INTRODUCTION}

The Apiaceae (previously Umbelliferae) is very well-known flowering plants family [1-2], and a fairly large family comprised of about 455 genera and over 3700 species in the world, mostly in the northern mild regions and high altitudes in the tropics [3-6]. The Seseli L. is one of the largest genera in the Apiaceae with 125 to 140 taxa referred to the genus in the world, contains herbaceous plants [2-7], as narrow endemics [8] and 80 of which are distributed within Asia along with Europe, Africa, North America, and Australia [4,8-11]. The genus Seseli L. originates from the words "Seseli, seselis, or sesili" in Lantin words. Since ancient times Hippocrates and Dioscorides used it in folk medicine [12-13]. On the other hand, the Seseli is represented by 12 taxa in the Flora of Turkey [2,7,14-15], and new species continue to be discovered every day [16-18]. Moreover, Seseli species have been used traditionally for human inflammation, swelling, rheumatism, pain, and the common cold [19]. Also, the species have been used in European traditional medicine widely, presenting antibacterial, antifungal, insect repellent, emmenagogue, antiflatulence, anti-inflammatory, antinociceptive, anti-tumor, anti-rheumatic activities, and protective effect on human lymphocytes DNA [20]. In Turkish folk medicine, S. tortuosum is used as an emmenagogue and anti-flatulence [21-22], and S. libanotis called "Kelemkeşir" or "kelemenkeşir" in Turkish, is used as a cheese preservative to provide aroma [23-24], besides the leaves of the species are consumed as a vegetable in eastern Turkey [22]. In the light of the traditional uses, many biological activities have been investigated on the Seseli species such as antioxidant [13,20,25-28], antimicrobial [27-29] anti-inflammatory [30-32], and cytotoxic effects [25,29]. The studies

How to cite this article: Önder A, Çınar AS, Ateş FB, Artiaga LN, Carbobonell-Barrachina AA. Chemical composition and cytotoxic potency of essential oil from Seseli petraeum M. Bieb. (Apiaceae). J Res Pharm. 2021; 25(3): 249-257. 
comprising the latest research, especially on essential oils, have great interest, mainly due to proper chemical characteristics and biological activities. The application of essential oils as anticancer factors has been defined with all details both in vitro and in vivo [33-35]. Also, the results obtained from the pre-kinetics studies on essential oils and phytochemicals were found to be quite positive [36]. Despite the potential of Seseli species to be valuable bioactive molecules and essential oil sources, their essential oils have also been poorly studied in terms of chemical and biological activity. Therefore, the current study, on Seseli petraeum M. Bieb. known as "Taş çaşırı, stone Seseli, taş Seseli" in Anatolia wildly, described as a perennial species with the characteristic fibrous collar [7] and has a few studies revealed from the literature survey [37-38], was performed to report the qualitative and quantitative analyses of the essential oil to better evaluation, and assessed the cytotoxicity of the oil against selected human cancer cells, testing several biochemical parameters.

\section{RESULTS and DISCUSSION}

Results of the chemical evaluation of essential oil composition revealed the presence of higher oil content in the fruits of S. petraeum by the yield of $1.5-2 \%$ obtained on a dry weight basis $(\mathrm{v} / \mathrm{w})$. The essential oil has been distilled as a pale-yellow color with an unusual resinous odor. Chemical profiling of essential oil from S. petraeum obtained by the hydro-distillation exhibited 55 components representing $100 \%$ of the oil by GC/MS analysis, as shown in Table 1. The major components have been found (Table 1) as carotol (17.25\%), $\gamma$-terpinene $(10.73 \%), \beta$-farnesene $(8.50 \%), p$-cymene $(7.93 \%)$, germacrene-D $(7.65 \%)$, and sabinene $(7.31 \%)$. In addition, an essential oil chromatogram of the species depicting variation in major constituents present in fruit oil is given in Figure 1.

Essential oils from Seseli L. species have been previously examined, and germacrene D (29.8\%), sabinene $(10.3 \%),(Z)-\beta$-ocimene $(9.8 \%)$ and limonene $(8.6 \%)$ ] on $S$. annuum L. [39]; sabinene $(17.7-25.1 \%)$ on $S$. buchtormense (Fischer) W. D. J. Koch [40]; a-pinene (26.2\% and 35.8\%), (E)-sesquilavandulol (11.8\% and 3.2\%) on S. campestre Besser fruits [41]; a-pinene $(38.6 \pm 0.5 \%), \beta$-pinene $(17.5 \pm 0.1 \%)$ and $(E)$-sesquilavandulol $(10.3 \pm 0.8 \%)$ on S. campestre Besser aerial parts [42]; myrcene $(29.2 \%)$, a-pinene $(18.6 \%, 21.2 \%), \beta$-pinene $(13.2 \%$, $14.2 \%)$ and limonene (10.6\%)] on S. tortuosum L. [43-44]; a-pinene (42.7-48.2\%) on S. pallasii Besser [45]; apinene $(23.3-37.8 \%)$, sabinene (12.9-14.2\%), $\beta$-phellandrene (5.1-17.4\%) on S. rigidum Waldst. \& Kit. [46-47]; carotol $(20.7 \%), \gamma$-terpinene $(11.3 \%)$, sabinene $(9.5 \%)$, germacrene D $(7.8 \%)$ on S. petraeum [38] have been found as main components. It is clear that almost the similar compounds have been identified in different concentrations in the oils of Seseli species.

In this study, besides the chemical composition of the oil, the cytotoxic acitivity of the essential oil of $S$. petraeum on cell growth of MCF-7 and A549 cancer cells were also evaluated first of all using the thiazolyl blue test (MTT) assay. The results showed that the oil has potent cytotoxic effects in treated cell lines, whereas it was much more effective on MCF-7 cells when compared to the A549 group (Table 2). The viable cell amount was significantly decreased from $100 \%$ to $76.17 \pm 3.31 \%, 57.62 \pm 6.44 \%$ and $43.63 \pm 2.28 \%$ at 100,200 and 500 $\mu \mathrm{g} / \mathrm{mL}$ concentrations in MCF-7 cells (Figure 2), respectively $(p<0.01)$. On the other hand, a significant decrease to $76.53 \pm 2.94 \%$ ( $p=0.0083$ ) was observed in A549 cells at only $500 \mu \mathrm{g} / \mathrm{mL}$ concentration. Therefore, the essential oil obtained from S. petraeum presented promising results. Although there are plenty of studies on the anticancer effect of essential oils, only a few studies have reported cytotoxic activities for the essential oils of some species belonging to Seseli genus. For example, $S$. tortuosum essential oil has been found cytotoxic to human cells in the concentrations higher than $0.64 \mu \mathrm{L} / \mathrm{mL}$ [29]. These effects might be major and minor constituents of the essential oils.

Essential oils are natural products obtained from aromatic plants and have numerous applications in many industrial branch [48]. Essential oils have also important effects such as antimicrobial, anticancer, antiinflammatory and antiviral etc. which are discussed in detail in a literature [49]. Utilizing the synergistic and additive effects of essential oils and their components is said to increase efficiency [50]. Sometimes, the absence of similar essential oil activity in isolated compounds has led to the idea that in medicinal plant preparations the major compounds are not always responsible for a biological effect [51]. Carotol stands out as the major component in the essential oil of Seseli species [52]. Although there is no study on carotol, a sesquiterpene compound, directly, it is known that sesquiterpenes are an effective secondary metabolites group [53]. A study has been already done on this subject $\beta$-2-himachalen-6-ol, a novel sesquiterpene from wild carrot (Daucus carota ssp. carota) exhibited potent anticancer activity against B16F-10, Caco-2, MB-MDA-231, A549 and SF-268 cancer cells lines $\left(\mathrm{IC}_{50} 13-4 \mu \mathrm{g} / \mathrm{mL} ; 58-18 \mu \mathrm{M}\right)$ [54], which is similar compound with carotol (a sesquiterpene alcohol from azulene group). 


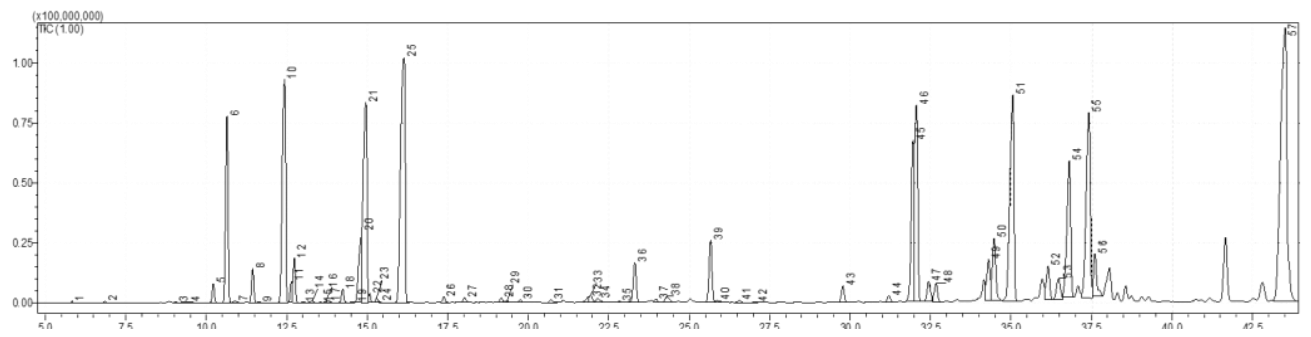

Figure 1. Model of the chromatogram obtained during the analysis of the essential oil of Seseli petraeum.

Table 1. The volatile composition of the essential oils from Seseli petraeum.

\begin{tabular}{|c|c|c|c|c|c|c|c|}
\hline \multirow{2}{*}{ Peak } & \multirow{2}{*}{ Compounds } & \multirow{2}{*}{$\begin{array}{c}\mathrm{RT} \\
(\mathrm{min})\end{array}$} & \multirow{2}{*}{$\begin{array}{c}\mathrm{KI} \\
(\exp )\end{array}$} & \multirow{2}{*}{$\begin{array}{c}\text { KI } \\
\text { (lit) }\end{array}$} & \multicolumn{2}{|c|}{ Relative abundance $(\%)$} & \multirow{2}{*}{$\begin{array}{c}\text { Mean } \\
(\%)\end{array}$} \\
\hline & & & & & Dil. 1:50 & Dil. 1:100 & \\
\hline 1 & Isobutyl acetate & 5.767 & 798 & 788 & 0.03 & 0.03 & 0.03 \\
\hline 2 & Hexanal & 6.800 & 834 & 818 & 0.03 & 0.03 & 0.03 \\
\hline 3 & Isovaleric acid & 8.983 & 908 & 888 & 0.01 & 0.01 & 0.01 \\
\hline 4 & Hexyl formate & 9.175 & 914 & 907 & 0.01 & 0.01 & 0.01 \\
\hline 5 & $a$-Thujene & 10.108 & 938 & 934 & 0.51 & 0.42 & 0.47 \\
\hline 6 & a-Pinene & 10.483 & 949 & 948 & 4.53 & 4.68 & 4.61 \\
\hline 7 & 2-Methyl-2-butenoic acid & 10.817 & 956 & 954 & 0.06 & 0.04 & 0.05 \\
\hline 8 & Camphene & 11.325 & 969 & 964 & 0.92 & 0.77 & 0.85 \\
\hline 9 & Verbenene & 11.592 & 975 & 968 & 0.02 & 0.02 & 0.02 \\
\hline 10 & Sabinene & 12.250 & 995 & 996 & 6.93 & 7.68 & 7.31 \\
\hline 11 & $\beta$-Pinene & 12.575 & 1000 & 1000 & 0.57 & 0.46 & 0.52 \\
\hline 12 & Myrcene & 12.708 & 1002 & 1006 & 1.06 & 0.92 & 0.99 \\
\hline 13 & 2-Amylfuran & 12.933 & 1008 & 1010 & 0.02 & 0.01 & 0.02 \\
\hline 14 & 6-Methyl-3,5-heptadien-2-one & 13.208 & 1014 & 1064 & 0.05 & 0.04 & 0.05 \\
\hline 15 & 1-Octen-3-ol & 13.475 & 1020 & 1009 & 0.00 & 0.00 & $\operatorname{tr}$ \\
\hline 16 & a-Phellandrene & 13.625 & 1023 & 1015 & 0.02 & 0.02 & 0.02 \\
\hline 17 & $\delta$-3-Carene & 13.758 & 1025 & 1021 & 0.06 & 0.05 & 0.06 \\
\hline 18 & $a$-Terpinene & 14.117 & 1035 & 1030 & 0.40 & 0.32 & 0.36 \\
\hline 19 & Octanal & 14.442 & 1042 & 1029 & 0.03 & 0.03 & 0.03 \\
\hline 20 & Limonene & 14.633 & 1046 & 1045 & 1.57 & 1.73 & 1.65 \\
\hline 21 & p-Cymene & 14.808 & 1051 & 1048 & 8.09 & 7.77 & 7.93 \\
\hline 22 & $\beta$-Phellandrene & 15.100 & 1054 & 1050 & 0.15 & 0.16 & 0.16 \\
\hline 23 & 1,8-Cineole & 15.233 & 1058 & 1055 & 0.13 & 0.10 & 0.12 \\
\hline 24 & $\beta$-Ocimene & 15.392 & 1061 & 1050 & 0.02 & 0.02 & 0.02 \\
\hline 25 & $\gamma$-Terpinene & 15.892 & 1077 & 1075 & 10.25 & 11.21 & 10.73 \\
\hline 26 & Terpinolene & 17.300 & 1103 & 1101 & 0.17 & 0.14 & 0.16 \\
\hline 27 & cis-Sabinene hydrate & 17.900 & 1116 & 1099 & 0.16 & 0.15 & 0.16 \\
\hline 28 & Linalool & 19.083 & 1140 & 1140 & 0.13 & 0.12 & 0.13 \\
\hline 29 & Nonanal & 19.300 & 1144 & 1130 & 0.04 & 0.04 & 0.04 \\
\hline 30 & trans-Sabinene hydrate & 19.650 & 1152 & 1135 & 0.09 & 0.08 & 0.09 \\
\hline 31 & $a$-Terpineol & 20.600 & 1172 & 1166 & 0.11 & 0.09 & 0.10 \\
\hline 32 & cis-Pinocarveol & 21.658 & 1195 & 1184 & 0.22 & 0.18 & 0.20 \\
\hline 33 & Citral & 21.908 & 1197 & 1213 & 0.19 & 0.16 & 0.18 \\
\hline 34 & cis-Verbenol & 22.075 & 1202 & 1188 & 0.14 & 0.11 & 0.13 \\
\hline 35 & (E)-2-Nonenal & 22.767 & 1215 & 1185 & 0.03 & 0.02 & 0.03 \\
\hline 36 & Terpinen-4-ol & 23.083 & 1225 & 1217 & 1.39 & 1.20 & 1.30 \\
\hline 37 & Estragole & 23.908 & 1239 & 1228 & 0.12 & 0.10 & 0.11 \\
\hline 38 & Verbenone & 25.492 & 1252 & 1245 & 2.06 & 1.82 & 1.94 \\
\hline 39 & Carvacrol methyl ether & 25.825 & 1274 & 1272 & 0.12 & 0.09 & 0.11 \\
\hline 40 & Neral & 26.450 & 1278 & 1276 & 0.08 & 0.07 & 0.08 \\
\hline 41 & Geraniol & 26.942 & 1302 & 1301 & 0.02 & 0.02 & 0.02 \\
\hline 42 & Carvacrol & 29.525 & 1340 & 1329 & 0.70 & 0.51 & 0.61 \\
\hline 43 & $\delta$-Elemene & 31.083 & 1360 & 1361 & 0.27 & 0.21 & 0.24 \\
\hline 44 & a-Amorphene & 31.717 & 1407 & 1433 & 5.53 & 5.07 & 5.30 \\
\hline 45 & (Z)-a-Farnesene & 32.050 & 1417 & 1433 & 4.85 & 5.98 & 5.42 \\
\hline 46 & $\beta$-Elemene & 32.350 & 1422 & 1422 & 0.82 & 0.70 & 0.76 \\
\hline 47 & $a$-Bergamotene & 32.608 & 1458 & 1456 & 0.79 & 0.59 & 0.69 \\
\hline 48 & $\beta$-Caryophyllene & 34.242 & 1461 & 1462 & 1.55 & 1.36 & 1.46 \\
\hline 49 & $\beta$-Farnesene & 34.400 & 1475 & 1471 & 2.43 & 2.16 & 2.30 \\
\hline 50 & $a$-Humulene & 34.750 & 1498 & 1497 & 8.43 & 8.57 & 8.50 \\
\hline 51 & $\gamma$-Cadinene & 36.333 & 1509 & 1511 & 1.00 & 0.84 & 0.92 \\
\hline 52 & $\gamma$-Muurolene & 36.642 & 1514 & 1511 & 5.61 & 5.18 & 5.40 \\
\hline 53 & Germacrene-D & 37.225 & 1528 & 1521 & 7.75 & 7.54 & 7.65 \\
\hline 54 & $\beta$-Bisabolene & 37.592 & 1532 & 1536 & 1.39 & 1.34 & 1.37 \\
\hline 55 & Carotol & 43.142 & 1573 & 1574 & 16.82 & 17.68 & 17.25 \\
\hline
\end{tabular}

10 most abundant compounds are highlighted in bold. Tr: trace amount 
As a result, the fruit essential oil of S. petraeum is characterized by the presence of carotol (as major one), $\gamma$-terpinene, $\beta$-farnesene, $p$-cymene, germacrene- $\mathrm{D}$, and sabinene. Carotol has been shown to have cytotoxic activity against green monkey kidney (VERO) and human pharynx squamous cell carcinoma $(\mathrm{FaDu})$ cell lines [55]. On the other hand, the cytotoxic action against cancer cells of polar compounds derived from carotol, such as hydroinene, has also been demonstrated [56]. Thus, the in vitro anticancer effects may possible due to the action of one of the major compounds, as example carotol, or due to the synergistic effect of all components along with minor ones or major compounds. Further studies must be carried out to understand better the basic mechanism involved in the anticancer activity of this essential oil.

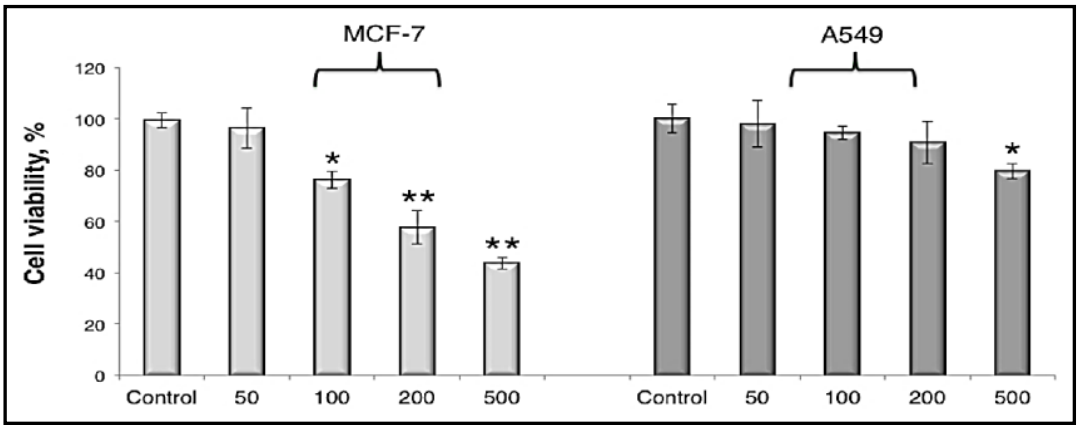

Figure 2. The effect of the essential oil of Seseli petraeum on cell growth of MCF-7 and A549 cancer cell lines. The MCF-7 and A549 cells were treated with different concentrations of essential oil $(50-500 \mu \mathrm{g} / \mathrm{mL})$ for $24 \mathrm{~h}$. Results are expressed as a percentage of viable cell amount. The non-treated cells were used as control. Each value represents the mean \pm SD from three independent experiments, done in triplicate $\left(^{*} p<0.05,{ }^{* * *} p<0.0001\right.$, compared to control).

Table 2. The cell viability \% of the essential oil of Seseli petraeum treated cell lines.

\begin{tabular}{lccc}
\hline CELLS & Cell viability (\%) & IC $_{50}$ value $(\boldsymbol{\mu g} / \mathbf{m L})$ & $p$-value (vs. control) \\
\hline MCF-7 & & & \\
Control & $99.43 \pm 2.94$ & & $\mathrm{~ns}$ \\
$50 \mu \mathrm{g} / \mathrm{mL}$ & $96.31 \pm 7.93$ & 390.38 & 0.0004 \\
$100 \mu \mathrm{g} / \mathrm{mL}$ & $76.17 \pm 3.31$ & & $<0.0001$ \\
$200 \mu \mathrm{g} / \mathrm{mL}$ & $57.62 \pm 6.44$ & & $<0.0001$ \\
$500 \mu \mathrm{g} / \mathrm{mL}$ & $43.63 \pm 2.28$ & & \\
$\mathbf{A} 549$ & & $\mathrm{~ns}$ \\
Control & $100.01 \pm 5.49$ & 1220.74 & $\mathrm{~ns}$ \\
$50 \mu \mathrm{g} / \mathrm{mL}$ & $97.99 \pm 9.01$ & $\mathrm{~ns}$ \\
$100 \mu \mathrm{g} / \mathrm{mL}$ & $94.43 \pm 2.48$ & & 0.0083 \\
$200 \mu \mathrm{g} / \mathrm{mL}$ & $90.78 \pm 8.29$ & & \\
$500 \mu \mathrm{g} / \mathrm{mL}$ & $76.53 \pm 2.94$ & & \\
\hline
\end{tabular}

\section{CONCLUSION}

Essential oils are rather complex mixtures including many constituents, and this complexity often makes challenging to explain their activity patterns. There are many reports on the biological activity of the essential oils, commonly referred to as synergism, antagonism, and additivity. The essential oil of Seseli petraeum seemed to be rich in carotol $(17.25 \%)$ which is a sesquiterpene. The results demonstrated that $S$. petraeum essential oil has a cytotoxic effect being a potential source of bioactive compounds. This effect may result from the major compound carotol, as well as from the synergistic effect of the complex mixture, which can be elucidated by future designed studies. Scientific studies need to assure that the absence of cytotoxicity at concentrations with potent biological activity, to explore the potential use in pharmaceutical and medicinal treatments. In summary, sesquiterpenoid constituents were dominated in the essential oil of S. petraeum and look promising for possible anticancer activity. 


\section{MATERIAL AND METHODS}

\subsection{Plant material}

The aerial parts of Seseli petraeum were collected at the fruiting stage on 01/09/2016 from plants growing wild in the Northern Site of Anatolia (Turkey) called as Trabzon-Gümüşhane district. The fruits of the plant were separated for the experiments. Prof. Dr. Hayri DUMAN from the Department of Biology, Faculty of Science, Gazi University, Ankara/Turkey has identified voucher specimens and deposited in the Ankara University, Faculty of Pharmacy Herbarium (AEF) under the number of AEF 26910.

\subsection{Essential oil distillation}

The air-dried samples (fruits $65 \mathrm{~g}$ ) were separated and roughly crushed. The crashed fruits were subjected to hydro-distillation using a Clevenger-type apparatus for 3 hours. The essential oil was obtained by the yield of $1.5-2 \%$ on a dry weight basis ( $\% \mathrm{v} / \mathrm{w})$, and 55 components identified representing $100 \%$ of the oil. The essential oil was dried by anhydrous sodium sulfate and then stored in sealed vials at $-20^{\circ} \mathrm{C}$, stored in a glass vial in the dark at $4^{\circ} \mathrm{C}$ for further analysis.

\subsection{Chromatographic analyses of essential oil}

The isolation and identification of the volatile compounds were achieved in a gas chromatography (Shimadzu GC-17A coupled with a Shimadzu QP-5050A) / mass spectrometer detector (Shimadzu Corporation, Kyoto, Japan). A RESTEK Rxi-1301Sil MS column (60 m × $0.25 \mathrm{~mm}, 0.25 \mu \mathrm{m}$ film thickness; Teknokroma S. Coop. C. Ltd, Barcelona, Spain) were used in the GC/MS system. This is a new column providing great results regarding separation of peaks but there are not too many published references to compare retention indexes; however, recent references can be found [57-59]. Analyses were performed using the carrier gas He (Helium) at a flow rate of $0.6 \mathrm{~mL} / \mathrm{min}$ in a split ratio of 1:52, then the following program:

(a) $80^{\circ} \mathrm{C}$ for $0 \mathrm{~min}$

(b) increase of $3^{\circ} \mathrm{C} \mathrm{min}-1$ from 80 to $210^{\circ} \mathrm{C}$ and hold for $1 \mathrm{~min}$

(c) increase of $25^{\circ} \mathrm{C} \mathrm{m^{-1 }}$ from 210 to $300^{\circ} \mathrm{C}$ and kept for $3 \mathrm{~min}$

The temperatures of the injector and detector were $230^{\circ} \mathrm{C}$ and $300^{\circ} \mathrm{C}$, respectively. The analysis was carried out from 39 to $400 \mathrm{~m} / \mathrm{z}$, with an electronic impact (EI) of $70 \mathrm{eV}$, in $1 \mathrm{scan} / \mathrm{s}$ mode. The compounds were determined using three different analytical methods:

(1) Kovats Index (KI), calculated using standard of aliphatic hydrocarbons (range from C-5 to C-23)

(2) GC/MS retention times (Authentic standards were used for identification purposes) libraries)

(3) Mass spectrum (original chemical compound and collection of the NIST05 and Adams 2012 spectrum

Semi-quantification of the volatile compounds was performed on a Shimadzu 2010 gas chromatograph with the help of a flame ionization detector (GC/FID). The column and chromatographic conditions were the same as those described above for GC/MS analyses. The $\mathrm{N}_{2}$ (Nitrogen) was used as carrier gas (1 mL/min). Data handling was carried out using the GC solution 2.3 (Shimadzu). For the semi-quantification of volatile components, benzyl acetate was added as an internal standard at a concentration of $\sim 1 \mathrm{~g} / \mathrm{L}$ in chloroform (50 $\mu \mathrm{L})$; and this compound was used as an internal standard after checking that it was absent in the oil. The proposed conditions, it separates well from other volatile compounds.

\subsection{Identification of constituents}

The chemical constituents of the essential oil were identified by comparison of their mass spectral pattern. The retention indices, Kovats retention index (KI), with those of components registered in commercial libraries (NIST05 and Adams 2012), and literature data, or a laboratory-made database was created from original compounds.

\subsection{Cell culture and treatments}

MCF-7 (human breast cancer cells) and A549 (human lung cancer cells) were purchased from ATCC (Germany). The cells were cultured in DMEM (Lonza, Germany) medium supplemented with 10\% FBS (Lonza, Germany) in a $5 \% \mathrm{CO}_{2}$ incubator at $37^{\circ} \mathrm{C}$. The seeded cancer cells were grown as described previously [60]. Following an incubation for $24 \mathrm{~h}$, the cells were treated with different concentrations of the essential oil from Seseli petraeum and incubated for $24 \mathrm{~h}$ under the same conditions. The stock solution for oil was prepared in DMSO with $0.01 \%$ final concentration. The non-treated cells were used as control. 


\subsection{Cytotoxicity assay}

\subsubsection{Cell proliferation assay}

The effect of the oil on cell proliferation in MCF-7 and A549 cells were determined by MTT assay. The cells were plated at a density of $1 \times 10^{4}$ cell/well and treated with 50,100, 200, and $500 \mu \mathrm{g} / \mathrm{mL}$ of the oil for 24 $\mathrm{h}$. Following incubation, the medium was replaced with a fresh one, and a $5 \mathrm{mg} / \mathrm{mL}$ MTT solution was applied. The cells were incubated for 2 hours, and dimethylsulfoxide (DMSO) was used to dissolve the formazan crystals. The absorbance was recorded by a spectrophotometer at $540 \mathrm{~nm}$ (Thermo, Germany).

\subsection{Statistical analysis}

GraphPad Prism 6.0 version (GraphPad Software Inc.) was used to perform the statistical analyses. The results were given as mean \pm SD of three independent experiments and a one-way ANOVA test was applied for multiple comparisons. The statistical significances represent ${ }^{*} p<0.01$ and ${ }^{* *} p<0.0001$ from control.

Acknowledgments: A part of this study has been supported by a grant of Ankara University Scientific Research Projects (BAP), 18L0237002. Author thanks to the BAP for supporting this work.

Author contributions: Concept - A.O.; Design - A.O., F.B.A., Supervision - A.O.; Resources - A.O., A.S.C.; Materials A.S.C.; Data Collection and/or Processing - A.O., F.B.A, A.S.C.; Analysis and/or Interpretation - A.O., F.B.A., L.N.A., A.A.C.B.; Literature Search - A.O., A.S.C.; Writing - A.O., F.B.A; Critical Reviews - A.O., A.S.C., F.B.A., A.A.C.B., L.N.A.

Conflict of interest statement: The authors declared no conflict of interest.

\section{REFERENCES}

[1] Heywood VH. Flowering Plants of the World, Oxford University Press, Oxford, 1979, pp. 219.

[2] Davis PH, Mill RR, Tan K. Flora of Turkey and the East Aegean Islands, Edinburgh University Press, Edinburgh, 1988, pp. 265.

[3] Crowden RK, Harborn JB, Heywood VH. Chemosystematics of the Umbelliferae-A General Survey. Phytochemistry. 1969; 8(10): 1963-1984. [CrossRef]

[4] Pimenov MG, Leonov MU. The Genera of the Umbelliferae, Whistable Litho, Whistable, Kent, 1993.

[5] Heywood VH, Brummit RK, Culham A, Seberg O. Flowering Plant Families of the World. Firefly Books Buffalo, New York, USA, 2007, pp. 46.

[6] Sayed-Ahmada B, Taloua T, Saad Z, Hijazi A, Merah O. The Apiaceae: Ethnomedicinal Family as Source for Industrial Uses. Ind Crops Prod. 2017; 109: 661. [CrossRef]

[7] Hedge IC, Lamond JM. Seseli L. Flora of Turkey and the East Aegean Islands. In Davis PH. (Ed). Edinburgh University Press, Edinburgh, 1972, pp. 367.

[8] Lyskov D, Güner ED, Samigullin T, Duman H, Pimenov M. Molecular data to elucidate the taxonomy of Seseli sect. Seseli (Apiaceae) in the east Mediterranean and southern Europe Nord J Bot. 2018; 36(9): 2. [CrossRef]

[9] Pimenov MG, Leonov MV. The Asian Umbelliferae biodiversity database (ASIUM) with particular reference to South-West Asian taxa. Turk J Botany. 2004, 28(1): 139-145.

[10] Akalin Uruşak E, Kızılarslan Ç. Fruit anatomy of some Ferulago (Apiaceae) species in Turkey. Turk J Botany. 2013; 37(3): 434-445. [CrossRef]

[11] Aytaç Z, Duman H. A new species and two new records from Turkey. Turk J Botany. 2013; 37(6): 1055-1060. [CrossRef]

[12] Dioscorides P. De Materia Medica. Codex Neapolitanus Graecus 1 of the National Library of Naples, Militos Press, Athens, 2002, pp. 215.

[13] Stojkovic S, Petrovic S, Kukic J, Dzamic A, Ristic M, Milenkovic M, Glamoclija J, Sokovic M, Stojkovic D. Chemical composition and antimicrobial and antioxidant activity of Seseli rigidum flower essential oil. Chem Nat Compd. 2009; 45(2): 253-255. [CrossRef]

[14] Duman H. Seseli L. Flora of Turkey and the East Aegean Islands. In: Guner A, Ozhatay N, Ekim T, Baser KHC, (Eds). Edinburgh University Press, Edinburgh, 2000, pp. 141. 
[15] Ozhatay N, Akalin E, Ozhatay E, Unlu S. Rare and endemic taxa of Apiaceae in Turkey and their conservation significance. Istanbul J Pharm. 2009; 40(1): 1-10. [CrossRef]

[16] Guner ED, Duman H, Pinar NM. Pollen morphology of the genus Seseli L. (Umbelliferae) in Turkey. Turk J Bot. 2011; 35(2): 175. [CrossRef]

[17] Guner ED, Duman H. The revision of genus Seseli (Umbelliferae) in Turkey. Turk J Bot. 2013; 37(6): 1018-1037. [CrossRef]

[18] Çetin O, Şeker MO, Duran A. A new subspecies of Seseli gummiferum (Apiaceae) from Ilgaz Mountain National Park, Northern Turkey. PhytoKeys. 2015; 56: 99-110. [CrossRef]

[19] $\mathrm{Hu} \mathrm{CQ}$, Chang JJ, Lee KH. Antitumor agents, 115. Seselidiol, a new cytotoxic polyacetylene from Seseli mairei. J Nat Prod. 1990; 53(4): 932-935. [CrossRef]

[20] Ilic MD, Jovanovic VPS, Mitic VD, Jovanovic OP, Mihajilov-Krstev TM, Markovic MS. Comparison of chemical composition and biological activities of Seseli rigidum fruit essential oils from Serbia. Open Chem. 2015; 13(1): 42-51. [CrossRef]

[21] Baytop T. Türkçe Bitki Adları Sözlüğü (Atatürk Kültür, Dil ve Tarih Yüksek Kurumu, TDKY 3578. TTK Basımevi, Ankara, 1994.

[22] Baytop T. Therapy with plants in Turkey (Past and Present). Nobel Medical Book House, İstanbul, 1999.

[23] Ozturk A, Ozturk S, Kartal S. The characteristics and uses of herbs added to herby cheeses in Van. The Herb Journal Systematic Botany. 2000; 7: 167-181.

[24] Ozturk S, Ercisli S. Chemical composition and in vitro antibacterial activity of Seseli libanotis. World J Microbiol Biotechnol. 2006; 22: 261-265. [CrossRef]

[25] Abbaskhan A, Choudhary MI, Ghayur MN, Parween Z, Shaheen F, Gilani AU, Maruyama T, Iqbal K, Tsuda Y. Biological activities of Indian Celery, Seseli diffusum (Roxb. Ex. Sm.) Sant. \& Wagh. Phytother Res. 2012; (26)5: 783786. [CrossRef]

[26] Matejic SJ, Dzamic AM, Mihajilov-Krstev T, Randelovic VN, Krivosej ZD, Marin PD. Total phenolic content, flavonoid concentration, antioxidant and antimicrobial activity of methanol extract from three Seseli L. Taxa. Cent Eur J Biol. 2012; 7: 1116-1122. [CrossRef]

[27] Jakovljevic D, Vasic S, Stankovic M, Comic L, Topuzovic M. In vitro biological activity of secondary metabolites from Seseli rigidum Waldst. et Kit. (Apiaceae). Acta Biol Hung. 2015; 66(4): 395-405. [CrossRef]

[28] Stankov Jovanovic V, Smonovic S, Ilic M, Markovic M, Mitic V, Djordjevic A. Chemical composition, antimicrobial and antioxidant activities of Seseli pallasii Besser. (syn Seseli varium Trev.) essential oils. Rec Nat Prod. 2016; 10(3): 277286.

[29] Goncalves MJ, Tavares AC, Cavaleiro C, Cruz MT, Lopes MC, Canhoto J, Salgueiro L. Composition, antifungal activity and cytotoxicity of the essential oils of Seseli tortuosum L. and Seseli montanum subsp. peixotoanum (Samp.). M. Lainz from Portugal. Ind Crops Prod. 2012; 39: 204. [CrossRef]

[30] Khan S, Shehzad O, Cheng MS, Li RJ, Kim YS. Pharmacological mechanism underlying anti-inflammatory properties of two structurally divergent coumarins through the inhibition of pro-inflammatory enzymes and cytokines. J Inflamm Res. 2015; 12: 47. [CrossRef]

[31] Chun J, Tosun A, Kim YS. Anti-inflammatory effect of corymbocoumarin from Seseli gummiferum subsp. corymbosum through suppression of NF-кB signaling pathway and induction of HO-1 expression in LPS-stimulated RAW 264.7 cells. Int Immun. 2016; 31: 207-215. [CrossRef]

[32] Tosun A, Chun J, Jerkovic I, Marijanovic Z, Fenu MA, Aslan SS, Tuberoso CIG, Kim YS. Chemical profiles and antiinflammatory activity of the essential oils from Seseli gummiferum and Seseli corymbosum subsp. corymbosum. Nat Prod Comm. 2016; 11(10): 1523-1526. [CrossRef]

[33] Bhalla Y, Gupta VK, Jaitak V. Anticancer activity of essential oils: A review. J Sci Food Agric. 2013; 93(15): 3643-3653. [CrossRef]

[34] Blowman K, Magalhaes M, Lemos MFL, Cabral C, Pires IM. Anticancer properties of essential oils and other natural products. J Evid Based Complementary Altern Med. 2018; 7: 1-12. [CrossRef]

[35] Andrade MA, Braga MA, Cesar PHS, Trento MVC, Esposito MA, Silva LF, Marcussi S. Anticancer properties of essential oils: An overview. Curr Cancer Drug Targets. 2018; 18(10): 957-966. [CrossRef] 
[36] Aras A, Iqbal MJ, Naqvi SK, Gercek YC, Boztas K, Gasparri ML, Shatynska-Mytsyk I, Fayyaz S, Farooqi AA. Anticancer activity of essential oils: targeting of protein networks in cancer cells. Asian Pac J Cancer Prev. 2014; 15(19): 8047-8050. [CrossRef]

[37] Kupeli E, Tosun A, Yesilada E. Anti-inflammatory and antinociceptive activities of Seseli L. species (Apiaceae) growing in Turkey. J Ethnopharmacol. 2006; 104(3): 310-314. [CrossRef]

[38] Tosun A, Kurkcuoglu M, Dogan E, Duman H, Baser KHC. Essential oil composition of Seseli petraeum M. Bieb. and Seseli andronakii Woron. growing in Turkey. Flavour Fragr J. 2006; 21: 257-259. [CrossRef]

[39] Milosavljevic S, Tesevic V, Vuckovic I, Jadranin M, Vajs V, Sokovic M, Janackovic P, Jovanovic A. Composition and antifungal activity of the essential oil of Seseli annuum wild-growing in Serbia. Fitoterapia. 2007; 78(4): $319-322$. [CrossRef]

[40] Tkachev AV, Korolyuk EA, König W, Kuleshova YV, Letchamo W. Chemical screening of volatile oil-bearing flora of Siberia VIII.: Variations in chemical composition of the essential oil of wild-growing Seseli buchtormense (Fisch. ex Sprengel) W. Koch from different altitudes of Altai Region. J Essent Oil Res. 2006; 18(1): 100-103. [CrossRef]

[41] Baser KHC, Ozek T, Kurkcuoglu M, Aytac Z. Essential oil of Seseli campestre Besser. J Essent Oil Res. 2000; 12(1): 105107. [CrossRef]

[42] Kaya A, Demirci B, Baser KHC. Composition of the essential oil of Seseli campestre Besser. growing in the Northwest Anatolia. Turk J Pharm Sci. 2010; (7)2: 161-166.

[43] Bader A, Caponi C, Cioni PL, Flamini G, Morelli I. Acorenone in the essential oil of flowering aerial parts of Seseli tortuosum L. Flavour Fragr J. 2003; 18: 57-58. [CrossRef]

[44] Habibi Z, Masoudi S, Rustaiyan A. Chemical composition of the essential oil of Seseli tortuosum L. ssp. Kiabii Akhani. from Iran. J Essent Oil Res. 2003; 15: 412-413. [CrossRef]

[45] Surucic R, Kundakovic T, Lakusic B, Drakul D, Milovanovic SR, Kovacevic N. Variations in chemical composition, vasorelaxant and angiotensin I converting enzyme inhibitory activities of essential oil from aerial parts of Seseli pallasii Besser (Apiaceae). Chem Biodivers. 2017; 14(15): 1-12. [CrossRef]

[46] Marcetic MD, Lakusic BS, Lakusic DV, Kovacevic NN. Variability of the root essential oils of Seseli rigidum Waldst. \& Kit. (Apiaceae) from different populations in Serbia. Chem Biodivers. 2013; 10(9): 1653-1666. [CrossRef]

[47] Marcetic M, Kovacevic N, Lakusic D, Lakusic B. Habitat-related variation in composition of the essential oil of Seseli rigidum Waldst. \& Kit. (Apiaceae). Phytochemistry. 2017; 135: 80-82. [CrossRef]

[48] Aziz ZAA, Ahmad A, Setapar SHM, Karakucuk A, Azim MM, Lokhat D, Rafatullah M, Ganash M, Kamal MA, Ashraf GM. Essential oils: Extraction techniques, pharmaceutical and therapeutic potential - A Review. Current Drug Metab. 2018; 9 (13): 1100-1110. [CrossRef]

[49] Bakkali F, Averbeck S, Averbeck D, Idaomar M. Biological effects of essential oils--a review. Food Chem Toxicol. 2008; 46(2): 446-475. [CrossRef]

[50] Galindo LA, Pultrini AM, Costa M. Biological effects of Ocimum gratissimum L. are due to synergic action among multiple compounds present in essential oil. J Nat Med. 2010; 64(4): 436-441. [CrossRef]

[51] Bassolé IHN, Juliani HR. Essential oils in combination and their antimicrobial properties. Molecules. 2012; 17: 39894006. [CrossRef]

[52] Chizzola R. Chemodiversity of essential oils in Seseli libanotis (L.) W.D.J.Koch (Apiaceae) in Central Europe. Chem Biodivers. 2019; 16(6): e1900059.

[53] Abu-Izneid T, Rauf A, Shariati MA, Khalil AA, Imran M, Rebezov M, Uddin MS, Mahomoodally MF, Rengasamy KRR. Sesquiterpenes and their derivatives-natural anticancer compounds: An update. Pharmacol Res. 2020; 161: 105165.

[54] Taleb RI, Najm P, Shebaby W, Boulos JC, Demirdjian S, Hariri E, El-Sibai M, Daher C, Mroueh M. $\beta$-2-himachalen-6ol: A novel anticancer sesquiterpene unique to the Lebanese wild carrot. J Ethnopharmacol. 2016; 190: 59-67.

[55] Sieniawska E, Swiatek Ł, Rajtar B, Kozioła E, Polz-Dacewicz M, Skalicka-Wózniak K. Carrot seed essential oilSource of carotol and cytotoxicity study. Ind Crops Prod. 2016; 92: 109-115.

[56] Bonikowski R, Kula J, Bujacz A, Bonikowska AW, Zakłos-Szyda M, Wysocki S. Hydroindene-derived chiral synthons from carotol and their cytotoxicity. Tetrahedron: Asymmetry. 2012; 23: 1038-1045.

[57] NIST, National Institute of Standards and Technology (2018). Retrieved from http://webbook.nist.gov/chemistry/name-ser.html 
[58] Sánchez-Bravo P, Noguera-Artiaga L, Carbonell-Barrachina AA, Sendra E. Fermented beverage obtained from hydroSOStainable pistachios. J Food Sci 2020; 85(10): 3601-3610. [CrossRef]

[59] Clemente-Villalba J, Ariza D, García-Garví JM, Sánchez-Bravo P, Noguera-Artiaga L, Issa-Issa H, Hernández F, Carbonell-Barrachina AA. Characterization and potential use of Diplotaxis erucoides as food ingredient for a sustainable modern cuisine and comparison with commercial mustards and wasabis. Eur Food Res Technol 2020; 246:1429-1438. [CrossRef]

[60] Cardile V, Russo A, Formisano C, Rigano D, Senatore F, Apostolides Arnold N, Piozzi F. Essential oils of Salvia bracteata and Salvia rubifolia from Lebanon: Chemical composition, antimicrobial activity and inhibitory effect on human melanoma cells. J Ethnopharmacol. 2009; 126(2): 265-272. [CrossRef]

This is an open access article which is publicly available on our journal's website under Institutional Repository at http://dspace.marmara.edu.tr. 